\section{Assessment of Stem Cell Profile in Ischemic Stroke}

\section{Bayu Winata Putera ${ }^{1,2 *}$, Andi Wijaya ${ }^{2,3}$, Irawan Yusuf ${ }^{1}$ and Aw Tar Choon ${ }^{2,4}$}

${ }^{1}$ Postgraduate Program in Clinical Biochemistry, Hasanuddin University, Makassar, Indonesia

${ }^{2}$ ProSTEM (Prodia Stem cell Indonesia), Central Jakarta, Indonesia

${ }^{3}$ Prodia Clinical Laboratory, Indonesia

${ }^{4}$ National University of Singapore, Singapore

\section{Abstract \\ Background}

Ischemic stroke remains a major health problem associated with high mortality and severe morbidity. The challenge of treatment is now to understand the process leading to endogenous neurorepair. Hematopoietic stem cell, mesenchymal stem cell, neural stem cell and endothelial progenitor cell are involved in endogenous neurorepair. These cells can contributes in recovery after stroke.

\section{Methods}

We enrolled ischemic stroke patient in the central hospital of the army (RSPAD) Jakarta. We collected patient's blood. We are grouping the patients into 3 groups. Group A, patient with onset stroke less than 7 days ( $<7$ days) ( 11 subjects), group $B$, patient with onset stroke $7-15$ days ( 12 subjects) and group $C$ patient with onset stroke more than 15 days (12 subjects). HSC, MSC, NSC and EPC were measured with flow cytometer.

*Corresponding author: Bayu Winata Putera, Postgraduate Program in Clinical Biochemistry, Hasanuddin University, Makassar, Indonesia, Tel: +62 411584200; E-mail: bayu.winata@prostem.co.id

Citation: Putera BW, Wijaya A, Yusuf I, Choon AT (2018) Assessment of Stem Cell Profile in Ischemic Stroke. J Transl Sci Res 1: 003.

Received: October 12, 2017; Accepted: October 08, 2018; Published: October 22, 2018

Copyright: (C) 2018 Putera BW, et al. This is an open-access article distributed under the terms of the Creative Commons Attribution License, which permits unrestricted use, distribution, and reproduction in any medium, provided the original author and source are credited.

\begin{abstract}
Results
Number of Mesenchymal Stem Cells (MSC) $(227.89+82.17)$ appears highest than other population of stem cell in group A, B and C. Our study show that number of Neural Stem Cells (NSC) increasing significantly with time of onset stroke. The number of Hematopietic Stem Cells (HSCs) $(p=0.007)$ and Endothelial Progenitor Cells $(E P C)(p=0.036)$ significantly different between onset group $A$ and $B$. The number of HSC $(p=0.000)$ also significantly different between onset group B and C likewise the number of MSC $(p=0.007)$. Our study also show that number of Neural Stem Cells (NSC) $(p=0.036)$ significantly different between onset group $\mathrm{A}$ and $\mathrm{C}$.
\end{abstract}

\section{Conclusion}

Our study suggest that HSC, MSC, NSC and EPC are mobilized at varying degrees into peripheral circulation after stroke.

Keywords: Endothelial Progenitor Cells (EPC); Hematopoietic Stem Cells (HSC); Ischemic stroke; Mesenchymal Stem Cells (MSC); Neural Stem Cells (NSC)

\section{Introduction}

Acute ischemic stroke is a common problem that carries a significant risk of death and disability [1]. According to the World Health Organization, 15 millions people worldwide suffer a stroke event each year. Of those 5 millions pass away and another 5 milions are permanently disabled [2]. There are approximately 12,1 per 1000 people in Indonesia [3]. Last decade has witnessed mounting evidence supporting the capacity of bone marrow derived stem cells to mobilize from bone marrow to peripheral blood and finding their way to the injured brain [4]. This mechanism called homing. Bone marrow consist of heterogeneous population stem cells, with Hematopoietic Stem Cells (HSC) and Mesenchymal Stem Cells (MSC) as the two most studied bone marrow derived stem cells. Additionally, Endothelial Progenitor Cells (EPC) and Neuron Stem Cells (NSC) have been studied and involved in endogenous neurorepair process after stroke [4].

HSC are quiescent cells with self renewal capacity and the ability to generate all mature blood cells [5]. HSC normally reside in specialized niches in the bone marrow that help maintain their quiscence and long term repopulating activity. There is emerging evidence that certain cytokines induced during inflammation have significant effects on HSC in bone marrow [5]. In pathofisiologi of stroke, there is inflammation process included [6]. In stroke condition, there are increase production of mature effects cell from lineage-hematopietic stem cells and facilitate the mobilization of mature effector cells from the bone marrow to blood. Recent evidence suggests that Hematopoietic Stem Cells (HSC) also direct targets of inflammatory signaling [5]. HSC will homing to inflammation site. HSC also have ability to differentiate into immun cells which have a play role in inflammation [5]. Within 24 hours after ischemia, resident microglia become activated and migrate to the lession site. Immune cells attraction from blood circulation toward the ischemic lesion site is mediated by chemokines released, which also play a crucial role in recruitment of bone marrow-derived stem cells, including HSC, MSC, EPC and NSC [7]. 
Mesenchymal Stem Cells (MSC) have ability as an injury drugs store. In stroke condition, MSC secrete many cytokine for regenerative microenvironment [8]. In animal stroke model, transplantation of MSC have good efficacy. Therapeutic effect of MSC showed that there is increasing growth factor include brain-derived neurotropic factor $[9,10]$. These neurotrophic cytokine have been implicated to play an important role in the process of angiogenesis and neurogenesis. Endothelial Progenitor Cells (EPC) play role in angiogenesis [11] and Neuron Stem Cells (NSC) play role in neurogenesis [12]. Clinical trials on cell therapy have been intiated in stroke patients [4-7,13]. A better understanding of mechanisms homing of the cells from peripheral to the brain is likely to aid in optimizing cell therapy for stroke [7]. The aim of our study is to observe the stem cells profile in ischemic stroke.

\section{Materials and Methods}

\section{Subjects}

Subjects in this study were part of cohort study of ischemic stroke in the central hospital of army (RSPAD) Gatot Subroto Jakarta. Diagnosis of ischemic stroke was made using clinical examination and Magnetic Resonance Imaging (MRI) interpretation by neurologist. We are grouping the subjects into 3 group. Group A, subjects with onset stroke less than 7 days ( $<7$ days), group B, subjects with onset stroke between 7-15 days and group C subjects with onset stroke more than 15 days. This study was approved by ethics committee of Faculty of Medicine, Hasanuddin University Makassar, Indonesia with register number: UH14110578.

\section{Blood sampling and cell isolation}

$10 \mathrm{~mL}$ of blood was drawn from antecubital veinn of subjects and collected in a vacutainer containing 3.8\% buffered sodium heparin. Mononuclear cells (MNCs) were then isolated by density-gradient centrifugation of histopaque (Histopaque-1077, Sigma-Aldrich). Add $3 \mathrm{~mL}$ of whole blood onto $3 \mathrm{~mL}$ histopaque. Centrifuge for exactly 30 minutes at room temperature. After centrifugation, carefully aspirate the upper layer with a Pasteur pipette to within $0.5 \mathrm{~cm}$ of the opaque interface containing mononuclear cells. Discard upper layer. Carefully transfer the opaque interface with a pasteur pipette into a clean conical centrifuge tube. Wash the cells by adding $10 \mathrm{~mL}$ of isotonic Phospate Buffered Saline (PBS) solution and mix by gently drawing in and out of the pipette. Centrifuge for 10 minutes. Aspirate the supernatan and discard. Resuspend cell pellet with $5 \mathrm{~mL}$ of isotonic phosphate buffered saline solution and mix by gently drawing in and out of the pipette. Erythrocytes and granulocytes should pellet to the bottom of centrifuge tube. Mononuclear cells should band at the interface between the histopaque and plasma.

\section{Flow cytometry}

All samples were analyzed using a BD FACS Canto flow cytometer with 3 fluorescent parameters: Fluorescein Isothiocyanate (FITC), Phycoerythrin (PE) and Peridinin Chlorophyll Protein (PerCP). The Forward Scatter (FSC-H) and Side Scatter (SSC-H) of cells were measured using a linear scale. A stop criterion of 1 million events was used for all data acquisition. We are measured number of HSC, MSC, NSC and EPC using flow cytometer with gating strategy (Figure 1) and surface marker HSC with CD34 antibodies-FITC (130-081-001, Miltenyi Biotec GmbH) and CD45 antibodies-PerCP
(130-094-975, Miltenyi Biotec $\mathrm{GmbH}), \mathrm{MSC}\left(\mathrm{CD} 105^{+} / \mathrm{CD}^{+} 3^{+}\right.$ $\left.\mathrm{CD} 90^{+} / \mathrm{CD} 34 / \mathrm{CD} 45^{-}\right)$with human MSC analysis kit $(562245$, BD Biosciences), NSC with CD133 antibodies-PE (130-080-801, Miltenyi Biotec GmbH), CD34 antibodies-FITC (130-081-001, Miltenyi Biotec $\mathrm{GmbH})$ and CD45 antibodies-PerCP (130-094-975 Miltenyi Biotec $\mathrm{GmbH}$ ) and $\mathrm{EPC}$ with $\mathrm{CD} 34^{+} \mathrm{CD} 34$ antibodies-FITC (130-081-001, Miltenyi Biotec GmbH), CD133 antibodies PE and KDR antibodies (Sigma) and gating strategy below:

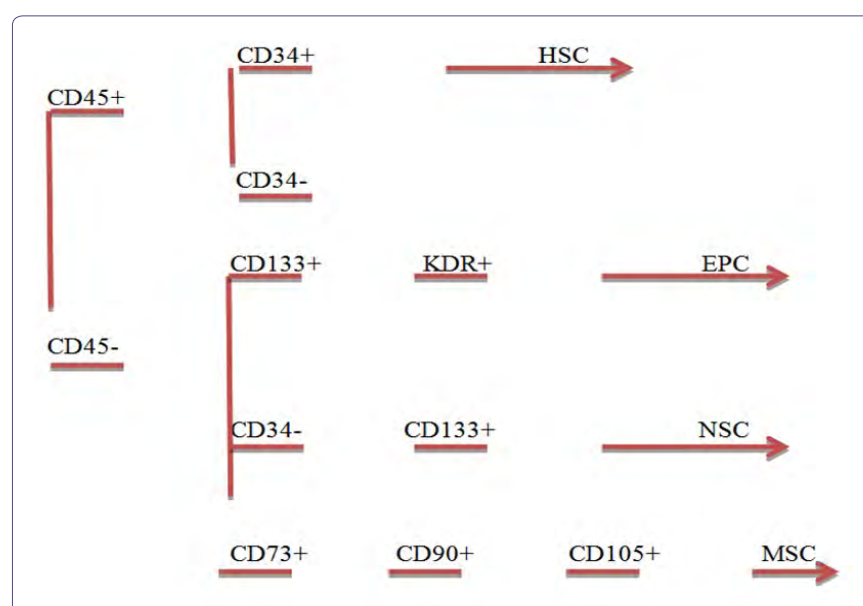

Figure 1: Gating strategy for HSC, MSC, NSC and EPC.

\section{Results}

We divided patients onto 3 groups of: 11 subjects group A, 12 subjects group B and 12 subjects group C. characterictics of subjects (Tables 1 and 2).

\begin{tabular}{|c|c|c|c|}
\hline Parameters & Group A & Group B & Group C \\
\hline Age (years) & $60 \pm 11.2$ & $58 \pm 10.3$ & $60 \pm 10.3$ \\
\hline Sex & - & - & - \\
\hline Male & 9 & 9 & 9 \\
\hline Female & 2 & 3 & 3 \\
\hline
\end{tabular}

\begin{tabular}{|c|c|c|c|}
\hline Variable & Min & Max & Mean \pm SD \\
\hline HSC $($ cells $/ \mathrm{ml})$ & 17 & 332 & $121.74 \pm 79.23$ \\
\hline MSC $($ cells $/ \mathrm{ml})$ & 129.5 & 656.25 & $227.89 \pm 82.17$ \\
\hline NSC $($ cells $/ \mathrm{ml})$ & 1.28 & 956 & $81.94 \pm 212$ \\
\hline EPC $($ cells $/ \mathrm{ml})$ & 1 & 100 & $10 \pm 15.48$ \\
\hline
\end{tabular}

Table 2: Number of stem cells.

Note: HSC: Hematopoietic Stem Cell; MSC: Mesenchymal Stem Cell; NSC: Neural Stem Cell; EPC: Endothelial Progenitor Cell.

\section{Discussion}

Migration of stem cells from bone marrow to target organ injury is important role for regeneration and repair. Bone marrow acts as a reservoir for multiple stem cells population including Hematopoietic Stem Cells (HSC), Mesenchymal Stem Cells (MSC) Endothelial 
Progenitor Cells (EPC) [8]. In healthy donors, the percentage of $\mathrm{CD} 34^{+}$cells among circulating total nucleated cells at steady state is $0.06 \%$ [14], the percentage of MSC among circulating total nucleated cells is $0.0019 \%$ [15] and the percentage of EPC level in normal control subjects without physical or pathological stimulation is around $1.5 \%$ [16]. These cells are mobilized at varying degrees into the peripheral circulation following injury [8]. Aim of our study is to investigate stem cells profile in ischemic stroke subjects. Our study show (Figure 2A) that number of Hematopoeitic Stem Cells (HSC) is the highest in group $C$, patients with onset stroke $>15$ days and the second in group A, patients with onset stroke $<7$ days. It is indicates that HSC have play role in $<7$ days after stroke and $>15$ days after stroke. This is appropriate with Wolf and Ley study in 2015. Study Wolf and Ley $[9,17]$ show that there is increasing number of HSCs after stroke because requirement of monocyte after stroke $[9,17]$.

Our study showed that Mesenchymal Stem Cell (MSC) is the highest number of stem cells in all group onset stroke. Number of MSC is highest in group B, patients with 7-15 days onset of stroke (Figure 2B). Our postulate that the peak of regeneration process induces MSC occurs in 7-15 days after onset stroke. As one of potential therapeutic arms, it has been demonstrated that transplantation with bone-marrow-derived mesenchymal stem cells can promote functional recovery [18] and nervous tissue repair [19] in a vast number of previous studies associated with stroke $[8,20,21]$. Mechanism is proposed to explain the succesful improvement of neural functional recovery through MSC administration that MSC secrete neurothropic factors that may induce the host ischemic brain to activate endogenous repair mechanisms [4]. Chopp, et al., [9] show that MSC produce Hepatocyte Growth Factor (HGF), Vascular Endothelial Growth Factor (VEGF) [22], nerve growth factor [15], Brain-Derived Neurotrophic Factor (BDNF) $[9,23,24]$, Basic Fibroblast Growth Factor (b-FGF) [25], Insulin Growth Factor-1 (IGF-1) [26] and Stromal Derived Factor (SDF)-1 [10,24]. These neurotrophic cytokines have been implicated to play an important role in the process of angiogenesis and neurogenesis. Besides secreting neurotropic factor, MSC also secreting exosome. Exosomes contain functional proteins, mRNAs, microRNAs, miRNA and tRNA species that play roles in intercellular communication [27]. Unfortunately, our study did not measure exosomes from MSC.

Angiogenesis is important for formation of new brain microvessels and functional recovery after ischemic stroke. Enhanced angiogenesis has been associated with function recovery following stroke [28,29]. EPC have been suggested to maintain angiogenesis and endothelial repair or protection. EPC contribute to neurovascular protection, angiogenesis and neurogenesis [30,31]. Our study demonstrated that EPC is mobilized into peripheral circulation from bone marrow after ischemic stroke. Moreover the number of EPC were higher in group $\mathrm{C}$, patient with $>15$ days of onset stroke (Figure 2C). Our postulate is EPC play role as neurovascular protection and neurogenesis in patient with $>15$ days of onset stroke. The underlying mechanims include that the regenerated blood vessels provide nutritive blood flow and EPC create a microenvironment for neural regeneration and survival, by secreting factors such as VEGF [27,32,33]. Furthermore, neuroblast migrate along these new vessels to achieve neurogenesis in peri-infarct area [34-36].

Many experimental studies have shown an increased proliferation of NSC in animal model of stroke which persist at least for four months after ischemia [28,37]. Our study also showed that Neural Stem Cell (NSC) increasing significant with time of onset stroke (Figure 2D) and number of NSC is highest in group C, patients with onset stroke $>15$ days. It indicates that NSC play important role in $>15$ days after stroke. The mechanisms underlying the improved functional recovery of ischemic stroke animal model subjected to NSCs therapy remain unclear. NSCs were found to differentiate into neuronal and/or glial phenotypes in most animal studies [28,30].

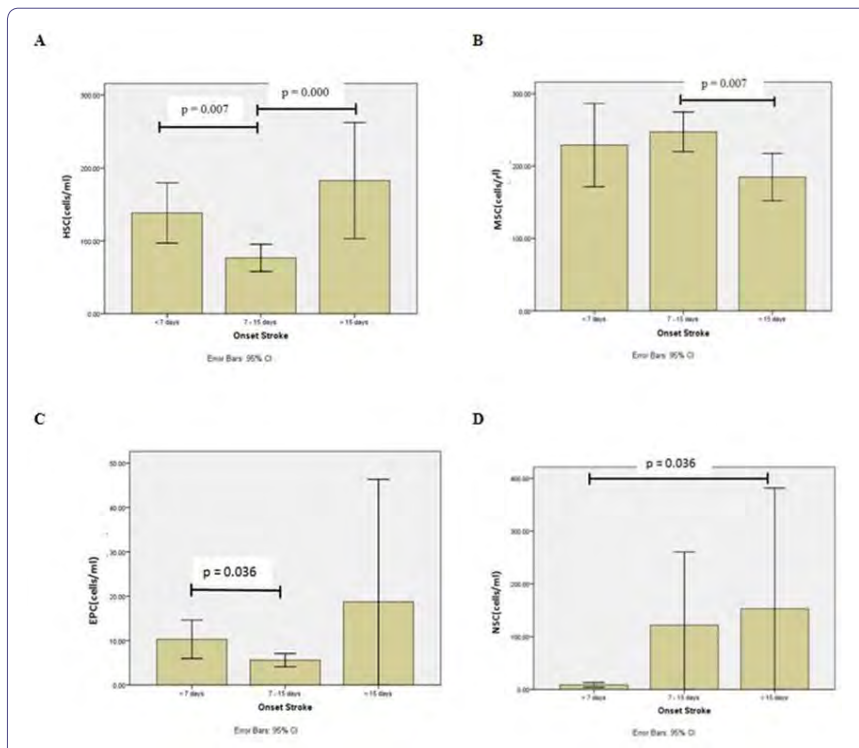

Figure 2: Graphic number of stem cells in stroke patient. (A) Hematopoietic Stem Cells (HSC); (B) Mesenchymal Stem Cells (MSC); (C) Endothelial Progenitor Cells (EPC); (D) Neural Stem Cells (NSC).

Our study demonstrated that HSC also mobilized into peripheral circulation from bone marrow after ischemic stroke. Central Nervous System (CNS)-induced cytokine cues may serve as migratory signals to HSC. The neurotransmitter-mediated interaction between CNS and bone marrow is bidirectional, with hematopoietic signaling mechanism equally contributing to HSC regulation of CNS function $[4,34]$. HSC can affect the nervous system and modulate its action [4,10,38]. Clinical data show that HSC mobilized into peripheral blood after ischemic stroke and directly related to recovery of function $[4,39]$. Our postulate mechanisms include: HSC contribute reduce cerebral postischemic inflammation, altenuate peripheral immune activation and mediate neuroprotection after ischemic stroke [17]. The limitation of our study is that we need higher number of patients for better the error bars especially for EPC and NSC. This is a preliminary case report and we plan to expand this study to monitor the same patient over time following onset of stroke to better understand the dynamics of these parameters following onset of stroke. Such understanding of the dynamic interplay of the parameters will allow us to better predict and develop method to improve outcome in stroke patients.

\section{Acknowledgement}

We thank to Prodia Stem Cell Indonesia (ProSTEM) and Prodia Education and Research Institute (PERI) for their support of this study. 


\section{References}

1. Benatar M (2005) Heparin use in acute ischaemic stroke: Does evidence change practice? QJM 98: 147- 152.

2. Guuerra-Crespo M, De la Herran-Arita AK, Boronat-Garcia A, Maya-Espinosa G, Garcia-Montes JR, (2012) Neural stem cells: Exogenous and endogenous promising therapies for stroke. Tao Sun (ed.), In: Neural stem cells and therapy, In-Tech, USA.

3. Ministry of Health Republik Indonesia (2014) Laporan Riset Kesehatan Dasar (RISKESDAS) 2013. Indonesia.

4. Borlongan CV (2011) Bone marrow stem cell mobilization in stroke: A 'bonehead' may be good after all! Leukemia 25: 1674-1686.

5. Schuettpelz LG, Link DC (2013) Regulation of hematopoietic stem cell activity by inflammation. Front Immunol 4: 204.

6. Lapidot T, Kollet O (2010) The brain-bone-blood triad: Traffic lights for stem-cell homing and mobilization. Hematology Am Soc Hematol Educ Program 2010: 1-6.

7. Schwarting S, Litwak S, Hao W, Bahr M, Weise J, et al. (2008) Hematopoietic stem cells reduce postischemic inflammation and amelioratew ischemic brain injury. Stroke 39: 2867-2875.

8. Liu Z, Li Y, Zhang ZG, Cui X, Cui Y, et al. (2010) Bone marrow stromal cells enhance inter-and intracortical axonal connections after ischemic stroke in adult rats. J Cereb Blood Flow Metab 30: 1288-1295.

9. Chopp M, Li Y (2002) Treatment of neural injury with marrow stromal cells. Lancet Neurol 1: 92-100.

10. Wolf D, Ley K (2015) Waking up the stem cell niche: How hematopoietic stem cells generate inflammatory monocytes after stroke. Circ Res 116 : 389-392.

11. Zhu JM, Zhao YY, Chen SD, Zhang WH, Lou L, et al. (2011) Functional recovery after transplantation of neural stem cells modified by brain-derived neurotrophic factor in rats with cerebral ischaemia. J Int Med Res 39: 488-498.

12. Hennemann B, Ickenstein $G$, Sauerbruch $S$, Luecke $K$, Haas $S$, et al (2008) Mobilization of CD34+ hematopoietic cells, colony-forming cells and long-term culture-initiating cells into the peripheral blood of patients with an acute cerebral ischemic insult. Cytotherapy 10: 303-311.

13. Kondziolka D, Wechsler L, Goldstein S, Meltzer C, Thulborn KR, et al. (2000) Transplantation of cultured human neuronal cells or patients with stroke. Neurology 55: 565-569.

14. Korbling M, Anderlini (2001) Peripheral blood stem cell versus bone marrow allotransplantation: Does the source of hematopoietic stem cells matter? Blood 98: 2900-2908.

15. Li S, Huang KJ, Wu JC, Hu MS, Sanyal M, et al. (2015) Periphera blood-derived mesenchymal stem cells: Candidate cells responsible for healing critical-sized calvarial bone defects. Stem Cells Transl Med 4 : 359-368.

16. Chen CH, Cheng BC, Leu S, Sun CK, Chua S, et al. (2010) Circulating level of endothelial progenitor cells in healthy Taiwanese. Acta Cardiol Sin 26: 94-101.

17. Schwarting S, Litwak S, Hao W, Bahr M, Weise J, et al. (2008) Hematopoietic stem cells reduce postischemic inflammation and ameliorate ischemic brain injury. Stroke 39: 2867-2875.

18. Liu Y, Zhang Y, Lin L, Lin F, Li T, et al. (2013) Effects of bone marrow-derived mesenchymal stem cells on the axonal outgrowth through activation of PI3K/AKT signaling in primary cortical neurons followed oxygen-glucose deprivation injury. PLoS One 8: 78514.

19. Li Y, Chen J, Chen XG, Wang L, Gautam SC, et al. (2002) Human marrow stromal cell therapy for stroke in rat: Neurotrophins and functional recovery. Neurology 59: 514-523.

20. Wei L, Fraser JL, Lu ZY, Hu X, Yu SP (2012) Transplantation of hypoxia preconditioned bone marrow mesenchymal stem cells enhances angiogenesis and neurogenesis after cerebral ischemia in rats. Neurobiol Dis 46: 635-645.
21. Dharmasaroja P (2009) Bone marrow-derived mesenchymal stem cells for the treatment of ischemic stroke. J Clin Neurosci 16: 12-20.

22. Chen X, Li Y, Katakowski M, Zhang L, Chen J, et al. (2002) Ischemic rat brain extracts induce human marrow stromal cell growth factor production. Neuropathology 22: 275-279.

23. Chen J, Zhang ZG, Li Y, Wang L, Xu YX, et al. (2003) Intravenous administration of human bone marrow stromal cells induces angiogenesis in the ischemic boundary zone after stroke in rats. Circ Res 92: 692-699.

24. Putera BW, Sartika CR, Wijaya A, Yusuf I, Tar-Choon A (2016) Levels of Stromal Derived Factor-1 (SDF-1) and Brain Derived Neurotropic Factor (BDNF) and Very Small Embryonic-Like Cells (VSEL) in ischemic stroke patients. International Journal of Translational Science 2016: 1-10.

25. Chen J, Li Y, Katakowski M, Chen X, Wang L, et al. (2003) Intravenous bone marrow stromal cell therapy reduces apoptosis and promotes endogenous cell proliferation after stroke in female rat. J Neurosci Res 73: 778786.

26. Zhang J, Li Y, Chen J, Yang M, Katakowski M, et al. (2004) Expression of insulin-like growth factor 1 and receptor in ischemic rats treated with human marrow stromal cells. Brain Res 1030: 19-27.

27. Shao L, Zhang Y, Lan B, Wang J, Zhang Z, et al. (2017) MiRNA-sequence indicates that mesenchymal stem cells and exosomes have similar mechanism to enhance cardiac repair. Biomed Res Int 2017: 4150705.

28. Hao L, Zou Z, Tian H, Zhang Y, Zhou H, et al. (2014) Stem cell-based therapies for ischemic stroke. Biomed Res Int 2014: 4687748.

29. Chu K, Kim M, Park KI, Jeong SW, Park HK, et al. (2004) Human neural stem cells improve sensorimotor deficits in the adult rat brain with experimental focal ischemia. Brain Res 1016: 145-153.

30. Zhao YH, Yuan B, Chen J, Feng DH, Zhao B, et al. (2013) Endothelial progenitor cells: Therapeutic perspective for ischemic stroke. CNS Neurosci Ther 19: 67-75.

31. Bogoslovsky T, Chaudhry A, Latour L, Maric D, Luby M, et al. (2010) Endothelial progenitor cells correlate with lesion volume and growth in acute stroke. Neurology 75: 2059-2062.

32. Imitola J, Raddassi K, Park KI, Mueller FJ, Nieto M, et al. (2004) Directed migration of neural stem cells to sites of CNS injury by the stromal cell-derived factor 1alpha/CXC chemokine receptor 4 pathway. Proc Natl Acad Sci USA 101: 18117-18122.

33. Schanzer A, Wachs FP, Wilhelm D, Acker T, Cooper-Kuhn C, et al. (2004) Direct stimulation of adult neural stem cells in vitro and neurogenesis in vivo by vascular endothelial growth factor. Brain Pathol 14: 237-248.

34. Thored P, Wood J, Arvidsson A, Cammenga J, Kokaia Z, et al. (2007) Long-term neuroblast migration along blood vessels in an area with transient angiogenesis and increased vascularization after stroke. Stroke 38: 3032-3039.

35. Zhang ZG, Chopp M (2009) Neurorestorative therapies for stroke: Underlying mechanisms and translation to the clinic. Lancet Neurol 8: 491-500.

36. Ohab JJ, Fleming S, Blesch A, Carmichael ST (2006) A neurovascular niche for neurogenesis after stroke. J Neurosci 26: 13007-13016.

37. Hallbergson AF, Gnatenco C, Peterson DA (2003) Neurogenesis and brain injury: Managing a renewable resource for repair. J Clin Invest 112: 11281133.

38. Dunac A, Frelin C, Popolo-Blondeau M, Chatel M, Mahagne MH, et al. (2007) Neurological and functional recovery in human stroke are associated with peripheral blood CD34+ cell mobilization. J Neurol 254: 327-332.

39. Taguchi A, Soma T, Tanaka H, Kanda T, Nishimura H, et al. (2004) Administration of $\mathrm{CD} 4^{+}$cells after stroke enhances neurogenesis via angiogenesis in a mouse model. J Clin Invest 114: 330-338. 


\section{Hit}

Journal of Anesthesia \& Clinical Care

Journal of Addiction \& Addictive Disorders

Advances in Microbiology Research

Advances in Industrial Biotechnology

Journal of Agronomy \& Agricultural Science

Journal of AIDS Clinical Research \& STDs

Journal of Alcoholism, Drug Abuse \& Substance Dependence

Journal of Allergy Disorders \& Therapy

Journal of Alternative, Complementary \& Integrative Medicine

Journal of Alzheimer's \& Neurodegenerative Diseases

Journal of Angiology \& Vascular Surgery

Journal of Animal Research \& Veterinary Science

Archives of Zoological Studies

Archives of Urology

Journal of Atmospheric \& Earth-Sciences

Journal of Aquaculture \& Fisheries

Journal of Biotech Research \& Biochemistry

Journal of Brain \& Neuroscience Research

Journal of Cancer Biology \& Treatment

Journal of Cardiology \& Neurocardiovascular Diseases

Journal of Cell Biology \& Cell Metabolism

Journal of Clinical Dermatology \& Therapy

Journal of Clinical Immunology \& Immunotherapy

Journal of Clinical Studies \& Medical Case Reports

Journal of Community Medicine \& Public Health Care

Current Trends: Medical \& Biological Engineering

Journal of Cytology \& Tissue Biology

Journal of Dentistry: Oral Health \& Cosmesis

Journal of Diabetes \& Metabolic Disorders

Journal of Dairy Research \& Technology

Journal of Emergency Medicine Trauma \& Surgical Care

Journal of Environmental Science: Current Research

Journal of Food Science \& Nutrition

Journal of Forensic, Legal \& Investigative Sciences

Journal of Gastroenterology \& Hepatology Research
Journal of Gerontology \& Geriatric Medicine

Journal of Genetics \& Genomic Sciences

Journal of Hematology, Blood Transfusion \& Disorders

Journal of Human Endocrinology

Journal of Hospice \& Palliative Medical Care

Journal of Internal Medicine \& Primary Healthcare

Journal of Infectious \& Non Infectious Diseases

Journal of Light \& Laser: Current Trends

Journal of Modern Chemical Sciences

Journal of Medicine: Study \& Research

Journal of Nanotechnology: Nanomedicine \& Nanobiotechnology

Journal of Neonatology \& Clinical Pediatrics

Journal of Nephrology \& Renal Therapy

Journal of Non Invasive Vascular Investigation

Journal of Nuclear Medicine, Radiology \& Radiation Therapy

Journal of Obesity \& Weight Loss

Journal of Orthopedic Research \& Physiotherapy

Journal of Otolaryngology, Head \& Neck Surgery

Journal of Protein Research \& Bioinformatics

Journal of Pathology Clinical \& Medical Research

Journal of Pharmacology, Pharmaceutics \& Pharmacovigilance

Journal of Physical Medicine, Rehabilitation \& Disabilities

Journal of Plant Science: Current Research

Journal of Psychiatry, Depression \& Anxiety

Journal of Pulmonary Medicine \& Respiratory Research

Journal of Practical \& Professional Nursing

Journal of Reproductive Medicine, Gynaecology \& Obstetrics

Journal of Stem Cells Research, Development \& Therapy

Journal of Surgery: Current Trends \& Innovations

Journal of Toxicology: Current Research

Journal of Translational Science and Research

Trends in Anatomy \& Physiology

Journal of Vaccines Research \& Vaccination

Journal of Virology \& Antivirals

Submit Your Manuscript: http://www.heraldopenaccess.us/Online-Submission.php 